OPEN ACCESS

Edited by:

Petar Knezevic

University of Novi Sad, Serbia

Reviewed by:

Paul Hyman,

Ashland University, United States

William Calero-Cáceres,

Technical University of Ambato,

Ecuador

*Correspondence:

Jonathan R. Iredell

jonathan.iredell@sydney.edu.au

Specialty section:

This article was submitted to

Antimicrobials, Resistance

and Chemotherapy,

a section of the journal

Frontiers in Microbiology

Received: 28 August 2020 Accepted: 10 December 2020

Published: 11 February 2021

Citation:

Khalid A, Lin RCY and Iredell JR

(2021) A Phage Therapy Guide

for Clinicians and Basic Scientists:

Background and Highlighting

Applications for Developing Countries.

Front. Microbiol. 11:599906

doi: 10.3389/fmicb.2020.599906

\section{A Phage Therapy Guide for Clinicians and Basic Scientists: Background and Highlighting Applications for Developing Countries}

\author{
Ali Khalid1,2, Ruby C. Y. Lin ${ }^{1,2,3}$ and Jonathan R. Iredell1,2,4* \\ ${ }^{1}$ Centre for Infectious Diseases and Microbiology, Westmead Institute for Medical Research, Sydney, NSW, Australia, \\ ${ }^{2}$ Faculty of Medicine and Health, School of Medical Sciences, The University of Sydney, Sydney, NSW, Australia, ${ }^{3}$ School \\ of Medical Sciences, University of New South Wales, Sydney, NSW, Australia, ${ }^{4}$ Westmead Hospital, Western Sydney Local \\ Health District, Sydney, NSW, Australia
}

Approximately $10 \%$ of global health research is devoted to $90 \%$ of global disease burden (the so-called "10/90 Gap") and it often neglects those diseases most prevalent in low-income countries. Antibiotic resistant bacterial infections are known to impact on healthcare, food security, and socio-economic fabric in the developing countries. With a global antibiotic resistance crisis currently reaching a critical level, the unmet needs in the developing countries are even more striking. The failure of traditional antimicrobials has led to renewed interest in century-old bacteriophage (phage) therapy in response to the urgent need to develop alternative therapies to treat infections. Phage therapy may have particular value in developing countries where relevant phages can be sourced and processed locally and efficiently, breaking specifically the economic barrier of access to expensive medicine. Hence this makes phage therapy an attractive and feasible option. In this review, we draw our respective clinical experience as well as phage therapy research and clinical trial, and discuss the ways in which phage therapy might reduce the burden of some of the most important bacterial infections in developing countries.

Keywords: bacteriophage, developing countries, antibiotic resistance, mortality, disease burden

\section{INTRODUCTION}

In 1990, the Global Burden of Disease Study (GBD) began to monitor the burden of specific health conditions in populations at national, regional and global levels in order to inform health policies especially in developing countries (Michaud, 2009). Almost two decades on, the 2017 GBD report indicated an improvement in the overall mortality from communicable infections but pointed to the continuing heavy socio-economic and public health burdens in developing countries (GBD Causes of Death Collaborators, 2018; Figure 1).

Infectious diseases disproportionately affect developing countries which, when combined with malnutrition, unhealthy living conditions and unsafe drinking water, drive morbidity and mortality and economic injury. The global expansion of antibiotic resistance (AMR) not only exacerbates this but also threatens to reverse the reductions in mortality and morbidity from endemic infections that are enjoyed in developing countries (Figure 1). A recent report estimated that AMR will contribute 
an excess of 10 million deaths and a GDP loss of $\$ 100$ trillion USD by 2,050 if effective measures are not taken to contain it (O’Neill, 2016).

Developing countries have in common limited healthcare systems and fragile economies and are ill-equipped to manage a growing infectious diseases burden despite all efforts from international health and humanitarian organizations (Bhutta et al., 2014).

In 2014, the first World Health Organisation (WHO) global surveillance report on antibiotic resistance showed that $>50 \%$ of clinically important bacteria from five of the six WHO regions have resistance against third generation cephalosporins, fluoroquinolones and carbapenems, and attributed $45 \%$ of deaths in Africa and South East Asia to multi-drug resistant (MDR) bacterial infections (WHO, 2014). Poor socioeconomic conditions, illiteracy, limited healthcare facilities, and unregulated antimicrobial use in humans and animals are important contributors to undesirable antibiotic resistance trends and their consequences (Aarestrup, 2012; Ayukekbong et al., 2017).

In recognition of this, a consortium of major pharmaceutical companies is creating a $\$ 1$ billion for-profit venture in support of small biotechnology companies developing mid-stage antibiotics (Silverman, 2020). While a comprehensive and integrated collaboration to antibacterial compounds and vaccines at global level is currently underway (Tong, 2020), the pathway to market access remains a barrier. The golden era of antibiotics continues to fade and there is an urgent need to develop and implement novel therapeutic strategies for infectious (Alanis, 2005).

The century-old science of bacteriophage (phage) therapy was largely neglected after the advent of antibiotics (Summers, 2001) but there remain distinct advantages. Phages are highly specific antibacterial agents that cause much less collateral damage to the microflora than conventional antibiotics that can be applied directly to human tissues without causing harm (d'Herelle, 1931; Weber-Dabrowska et al., 1987; Petrovic Fabijan et al., 2020a) and their abundance means they can be locally sourced, processed and packaged (Nagel et al., 2016).

Good Manufacturing Practice (GMP) preparations free of bacterial contaminations (especially lipopolysaccharides) for intravenous (IV) administration are a manufacturing challenge (not just in developing countries) but alternative administration of phages topically and orally (Figure 2) can be effective and feasible (Gill and Hyman, 2010). Here, we discuss some prominent infections for which phage therapy might be considered (Table 1).

\section{Typhoid}

Typhoid fever is an occasionally fatal systemic infection caused by Salmonella typhi and paratyphi strains, responsible for 1120 million cases and 128,000-161,000 deaths globally each year (Ochiai et al., 2008; Mogasale et al., 2014). A new typhoid conjugate vaccine with longer immunity and better safety profile in children $<2$ years age has recently been approved (Shakya et al., 2019) but currently available vaccines do not provide long-lasting immunity and vaccination has not been widely implemented in endemic countries.
Extensively drug resistant (XDR) Salmonella typhi (to first line antibiotics ampicillin, chloramphenicol and trimethoprimsulfamethoxazole, as well as fluoroquinolones and third generation cephalosporins) is now widespread in countries like Pakistan (Klemm et al., 2018) and is regularly imported to the United States (Chatham-Stephens et al., 2019), Australia (Howard-Jones et al., 2019), Canada (Wong et al., 2019), the United Kingdom (Klemm et al., 2018), and other countries in Europe (Kleine et al., 2017; Engsbro et al., 2019; Lopez-Segura et al., 2019; Procaccianti et al., 2020). An extensively drug resistant Salmonella typhi of a different haplotype (H58) from the epidemic strain in Pakistan (H55) has also emerged in Africa (Akinyemi et al., 2015; Phoba et al., 2017) which is responsive only to last-line hospital intravenous carbapenem antibiotics.

Physicians have used phages to treat typhoid for nearly a century (Smith, 1924) and historical anecdotes includes both oral and intravenous therapy (d'Herelle, 1931). Phages were used successfully in major outbreaks in Los Angeles from 1936 to 1949 (Knouf et al., 1946) and Quebec from 1946 to 1949 (Desranleau, 1948, 1949) and phage therapy for typhoid is once more in focus as antibiotics are failing. The widespread incidence of typhoid fever in low-income countries suggests that their natural predator phages should be present in the environment as well but international biobanks are already acting as vital repositories. Phages with lytic activity against an XDR Salmonella typhi strain isolated in the Democratic Republic of the Congo (Kakabadze et al., 2018) were identified from the phage library at the Eliava Phage Therapy Center in Georgia, where a Phage Biobank of obligately lytic phages against most common human pathogens is kept. Typhoid fever may be an ideal candidate for "re-introduction" of phage therapy.

\section{Cholera}

Cholera is a self-limiting, rapidly dehydrating secretory diarrheal disease of humans caused by toxigenic strains of the Gramnegative bacterium Vibrio cholerae. It is a major cause of mortality and morbidity in developing countries of Asia and Africa and is associated with poor sanitation and lack of clean drinking water (WHO, 2017a; Figure 3), with outbreaks often following war or natural disaster (Gupta et al., 2016). In 2018, nearly half a million cases and 3,000 deaths were reported (WHO, 2018). However, lack of diagnostic facilities, inadequate disease surveillance and fear of adverse effects on trade and tourism may all contribute to significant underreporting and WHO estimated the real case load to be nearly 3 million annually in endemic areas with 95,000 deaths (WHO, 2017a), more than half of these being in children $\leq 5$ years old (Ali et al., 2015).

Currently, there are three killed whole-cell oral vaccines prequalified by WHO for use in children $>1$ year and adults (WHO, 2017a; Seo et al., 2020) and a global stockpile has been created. Millions of doses have been administered and the WHO Global Task Force on Cholera Control aims to end cholera by 2030 through improved surveillance, vaccination, and implementation of improved water, sanitation, and hygiene in "hotspot" areas to reduce incidence and transmission (Zaman et al., 2020). Despite this, cholera has recently 


\section{Endemic bacterial infections in developing countries - Incidence, multidrug resistance and Case Fatality Rate (CFR)}
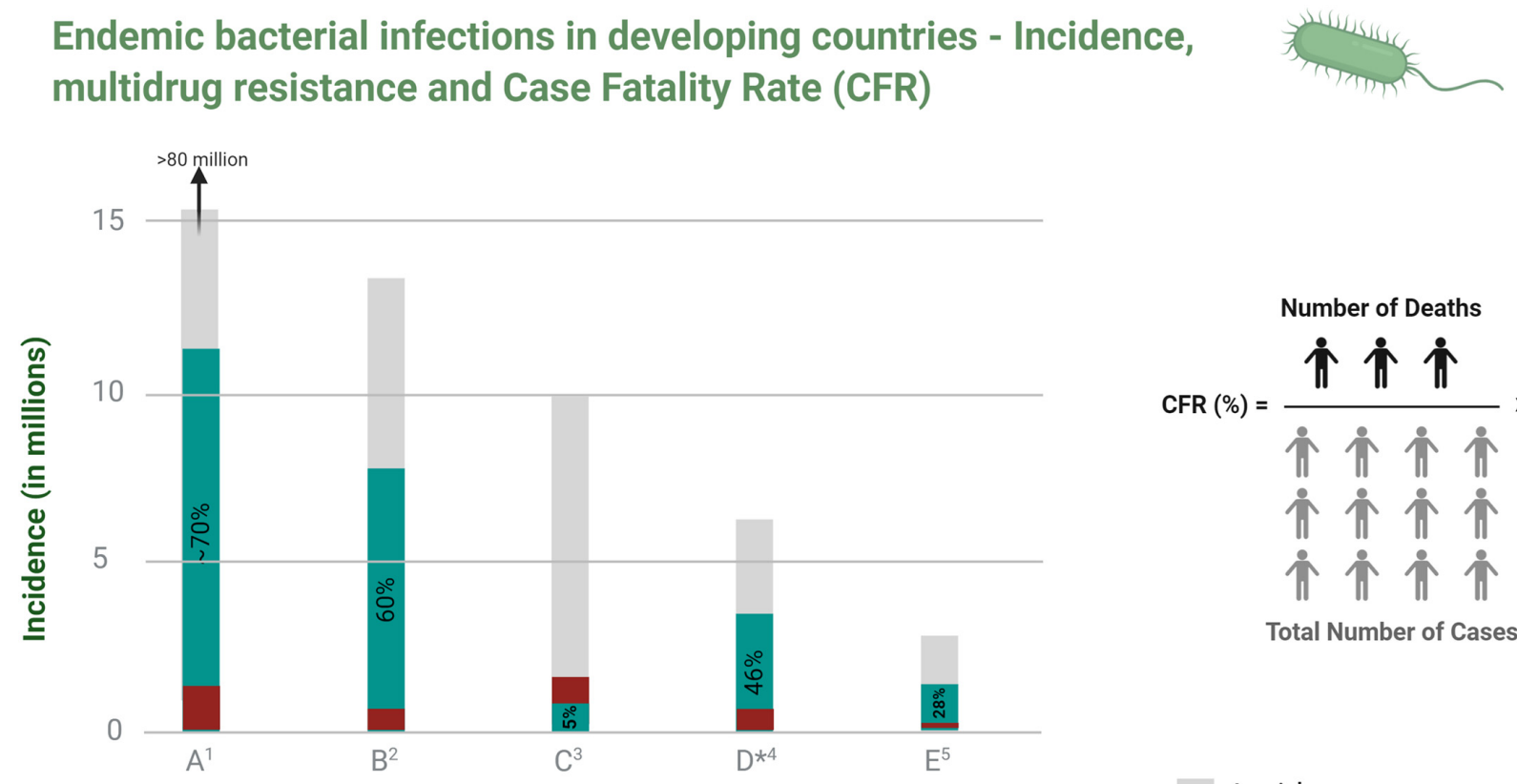
A) Shigellosis (Dysentery)
B) Typhoid fever
C) Tuberculosis
D) Diarrhea (other than dysentery and cholera)
E) Cholera

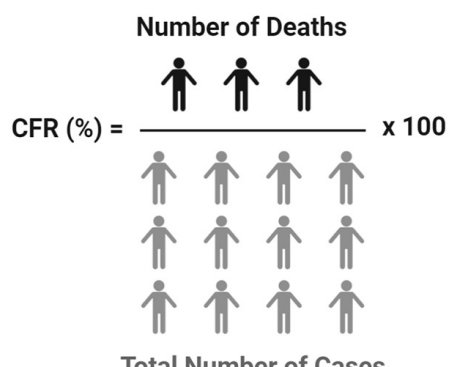

1. (WHO 2005) 2. (WHO 2018) 3. (WHO 2019) 4. (Khalil, Troeger et al. 2018) 5. (WHO 2017)

* Adjusted from WHO disease burden estimates after removing Shigella, cholera and viral diarrhea numbers

FIGURE 1 | Incidence, multidrug resistance and case fatality ratio of common bacterial infections in developing countries. Data is taken from studies cited in relevant disease sections in the text.

returned to the Americas with ongoing transmission in Haiti (Ganesan et al., 2020; Figure 3).

Management of cholera requires aggressive fluid and electrolyte replacement, but antibiotic treatment may decrease diarrhea by $50 \%$ and reduce shedding of viable organisms by days (Harris et al., 2012). Chemoprophylaxis within households may be effective but is not recommended by WHO because of the risk from AMR. Most $V$. cholerae in endemic areas are now resistant to the commonly used antibiotics (Dengo-Baloi et al., 2017; Rijal et al., 2019; Verma et al., 2019; Chatterjee et al., 2020).

An inverse relationship between the presence of virulent cholera phages and $V$. cholerae in environmental water samples coincides with the seasonality of disease occurrence in surrounding populations. This indicates a key role for phages in cholera epidemiology (Faruque et al., 2005) and makes biological control using phages an attractive option. Phages have been used to treat cholera since d'Herelle first linked the decline in mortality during a cholera epidemic in India in the 1920s to phages in stool and began to treat patients with oral vibriophages. He achieved a dramatic reduction in mortality with early use of oral phages (d'Herelle, 1929) and subsequent field trials achieved remarkable results in controlling localized epidemics (Summers, 1993). Several later trials reported successful prophylaxis (Sayamov, 1963) but relatively little effect on duration of established diarrheal illness (Monsur et al., 1970) or pathogen excretion (Marcuk et al., 1971).

Therapeutic effectiveness of cholera phages has also been shown in more controlled experiments using animal models, even with single phages (Bhandare et al., 2019). A "cocktail" of five specific phages given 6 and $12 \mathrm{~h}$ before $V$. cholerae challenge in adult rabbits slightly reduced both disease severity and bacterial load (Jaiswal et al., 2013) and another study using three phages in combination up to $24 \mathrm{~h}$ before $V$. cholerae challenge prevented infection in infant mouse and rabbit models, without emergence of resistance (Yen et al., 2017). It may be that poor choice of phages and/or trial design have contributed to previous failures and it seems clear that rigorous clinical trials of well-selected vibriophages are warranted.

\section{Shigellosis (Bacillary Dysentery)}

Shigellosis is a major public health problem in low-middle income countries and an important cause of morbidity in industrialized countries (Kotloff et al., 1999). It is generally a self-limiting diarrheal illness of up to 10 days but severe cramps and mucosal bleeding are not uncommon. Complications include sepsis, encephalopathy, hemolytic uremic syndrome and, rarely, 


\section{Routes of Bacteriophage Administration}

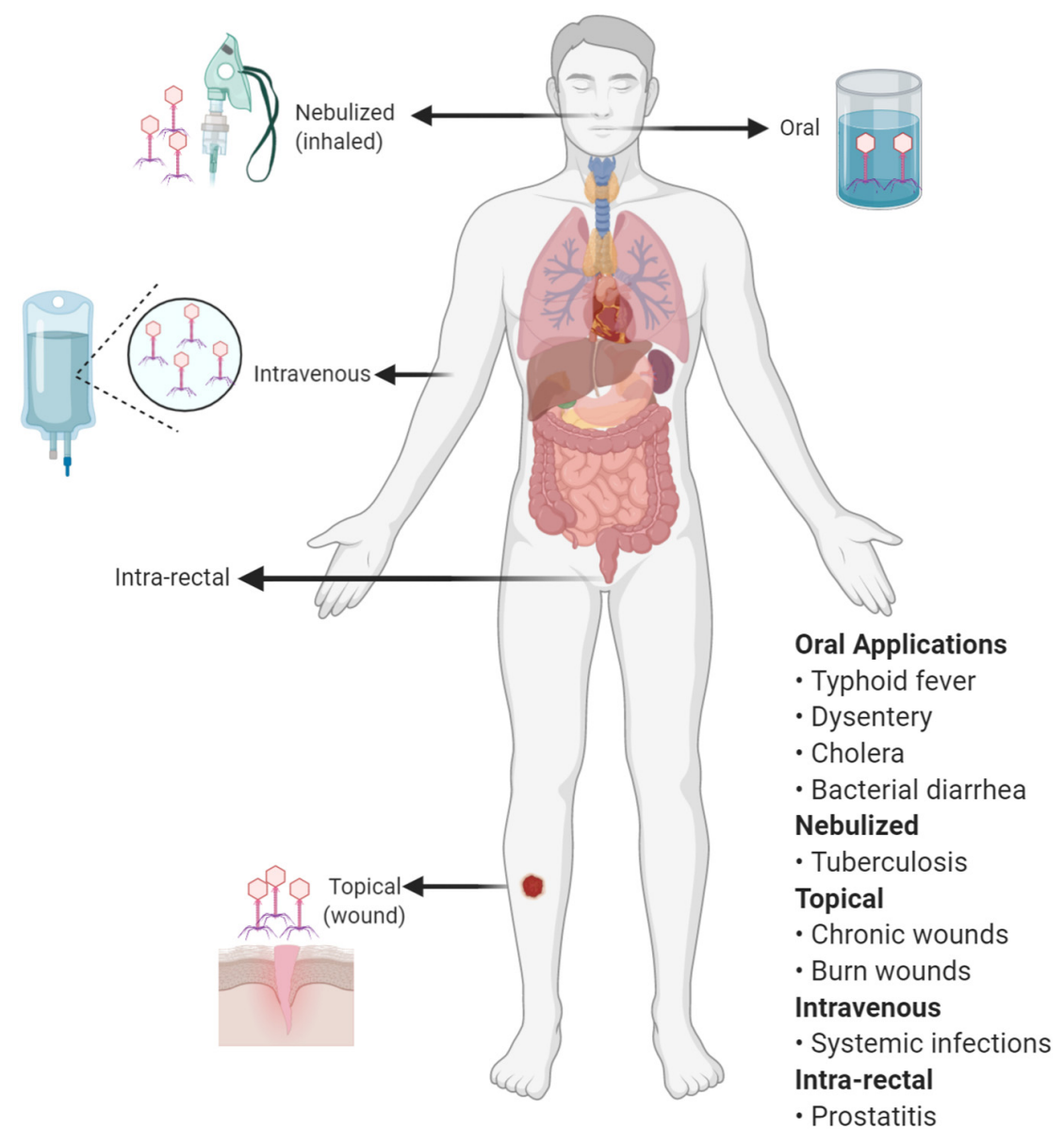

FIGURE 2 | Different routes of bacteriophage administration. The choice of a route will depend on the type of infection treated with phage therapy.

intestinal perforation (Khan et al., 2013). Case-fatality rates as high as $28 \%$ have been reported in children (Tickell et al., 2017).

Shigella is highly infectious, with very low infectious dose (DuPont et al., 1989) and efficient transmission through fecaloral route and in contaminated food, water and fomites (Figure 3). Common sources include salads, poultry, milk and dairy products, seafood and vegetables (Ahmed and Shimamoto, 2015) and Musca domestica, the common housefly with an affinity for human excrement, has also been incriminated as a mechanical vector (Cohen et al., 1991). In humans, maternal immunity may reduce incidence of Shigella infections in the first 6 months of life before immunity matures and becomes protective (Mani et al., 2016). Repeated infections, however, are not unusual because immunity is highly specific and multiple serotypes cause infection. This is most problematic in developing countries during summers and rainfall season (Figure 3) and where over-crowding and unsatisfactory hygienic is common (Puzari et al., 2018).

The four serologically distinguishable Shigella species are S. dysenteriae, S. flexneri, S. boydii, and S. sonnei, all of which cause shigellosis. Shigella causes diarrhea among travelers and military personnel from high-income countries (Khalil et al., 2018) and it is increasingly problematic in men who have sex with men communities (Heiman et al., 2014; Baker et al., 2018). Geographical variations and changing Shigella epidemiology (Tickell et al., 2017) makes management more difficult (Baker et al., 2018). There are several promising candidate in different stages of development (Walker, 2015) but no licensed vaccines are presently available.

Antimicrobial treatment can shorten the disease course, prevent complications and limit spread of infection through fecal shedding (Williams and Berkley, 2018). As with other endemic infections however, the treatment of shigellosis is complicated by increasing AMR. Currently, WHO recommends fluoroquinolones as first line treatment for all cases of dysentery and third-generation cephalosporins (ceftriaxone) are reserved as a second line or alternative option (WHO, 2005a) because there is high prevalence of resistance against ampicillin, tetracyclines, and sulphonamides. Quinolone, macrolide and third generation cephalosporin resistance is now increasingly widespread (Azmi et al., 2014; Chiou et al., 2016; Chung The et al., 2016) and horizontal transfer of resistance determinants between Shigella 
TABLE 1 | Important endemic bacterial infections in developing countries and their possible phage therapy solution.

\begin{tabular}{|c|c|c|c|c|c|c|}
\hline \multirow[t]{2}{*}{ Disease } & \multirow[t]{2}{*}{ *Incidence (in millions) } & \multirow[t]{2}{*}{ MDR/XDR } & \multicolumn{2}{|c|}{ Phage trials } & \multicolumn{2}{|c|}{ Phage solution } \\
\hline & & & Animals & Humans & Prophylaxis & Treatment \\
\hline Typhoid & $11-20$ & Yes/Yes & Yes & Yes & Yes & Yes \\
\hline Cholera & 2.86 & Yes/No & Yes & Yes & Yes & Yes \\
\hline Shigellosis (dysentery) & $>80$ & Yes/Yes & Yes & Yes & Yes & Yes \\
\hline Tuberculosis & 10 & Yes/Yes & Yes & No & Yes & No \\
\hline Acute bacterial diarrhea other than dysentery and cholera & $\sim 5-5.5$ & Yes/No & Yes & Yes & Yes & Yes \\
\hline
\end{tabular}

*The references for these data can be found in relevant sections.

and related Enterobacteriaceae may be contributing to the alarming increase in frequency of MDR globally (Mandomando et al., 2009; Chang et al., 2011; Gu et al., 2012; CDC, 2013; Aggarwal et al., 2016; Nuesch-Inderbinen et al., 2016; Hussen et al., 2019; Wang et al., 2019; Houpt et al., 2020).

Phages against Shigella flexneri may offer an alternative-they have been shown to prevent epithelial cell adhesion and invasion of phage-specific strains as well as other isolates of same species in a human intestinal organoid-derived infection model (LlanosChea et al., 2019). Early studies in mouse models showed phages can reach a range of anatomic sites including the brain (Dubos et al., 1943) and that phage therapy delayed up to 4 days can still prevent mortality (Morton and Engley, 1945).

Effective phages are relatively easily isolated, including from environmental water sources during dysentery outbreaks (Doore et al., 2018) and there is a rich history of phage therapy for shigellosis, with large and successful interventions reported since the 1930s (Chanishvili, 2012; Goodridge, 2013). Phages have been used successfully for dysentery prophylaxis (Babalova et al., 1968; Anpilov and Prokudin, 1984) and as biocontrol agents in water (Jun et al., 2016) and food (Zhang et al., 2013; Soffer et al., 2017).

\section{Acute Bacterial Diarrhea Due to E. coli}

Enteropathogenic E. coli (EPEC), enteroinvasive E. coli (EIEC), enteroaggregative E. coli (EAEC), enterotoxigenic E. coli (ETEC), Shiga toxin-producing E. coli (STEC), and diffusely adherent E. coli (DAEC) are distinguished on the basis of specific virulence properties (Croxen et al., 2013). EPEC and ETEC are endemic in developing countries where ETEC strains are a major cause of traveler's diarrhea while STEC causes large outbreaks around the world and, like Shigella, may be complicated by haemorrhagic colitis and haemolytic uremic syndrome (HUS) (Rojas-Lopez et al., 2018). The more than 6 billion cases and 1.5 million deaths in all age groups from diarrheal illness globally (Gregory et al., 2018; Spencer et al., 2018) include both viral and bacterial etiologies, but ETEC is in the top 10, accounting for more than 50,000 deaths in 2016, predominantly in young children in sub-Saharan Africa and South Asia (Khalil et al., 2018).

There is a steady rise in antibiotic resistance among diarrheagenic E. coli with many developing countries reporting $>70 \%$ of isolates to be MDR (Nguyen et al., 2005; GebreSilasie et al., 2018; Zhang et al., 2018). The WHO does not recommend routine use of antimicrobials to treat diarrhea where it is not possible to initially distinguish between etiological agents, because their efficacy is limited (WHO, 2005b) and in order to minimize selection for resistance (Laxminarayan et al., 2013). An oral, live attenuated recombinant vaccine (ACE527) was shown to generate strong immune response against ETEC in human volunteers (Darsley et al., 2012; Harro et al., 2019) but is not yet widely available.

Phage preparations have been used to treat potentially lethal enteropathogenic E. coli infection in calves, piglets and lambs (Smith and Huggins, 1982, 1983; Smith et al., 1987) and a large Phase I/II trial for the treatment of pediatric E. coli diarrhea established safety of orally administered phages in children but failed to significantly improve symptoms or outcomes (Sarker et al., 2016). Inadequate strain coverage, gastric acid neutralization and low pathogen density (for phage amplification) may be contributors to these unsatisfactory outcomes (Brussow, 2019) and need to be considered in future study designs.

\section{Foodborne Diseases}

Foodborne diseases (FBD) are defined as any illness caused by the ingestion of contaminated food or drink. The FBD disease spectrum ranges from gastrointestinal symptoms (most common) to debilitating chronic conditions including neurological and immunological disorders as well as multi-organ failure, cancer, and death (Grace, 2015). Until recently, data on the incidence of FBD and its associated costs were mostly limited to high-income countries as many developing countries lack reliable data on the incidence of FBD.

The annual global incidence of FBD was recently estimated to exceed 600 million cases and 420,000 deaths annually (WHO, 2015), largely experienced in low-middle income countries (LMICs) with less well developed food safety and regulatory and reporting systems (Grace, 2015). Total productivity loss is estimated at more than US\$95 billion in LMICs with another \$15 billion USD spent on treatment (World Bank Group, 2018) and biological pathogens are the most important food safety risks in developing countries (Käferstein, 2003). Rapid urbanization is a key factor in developing countries with marked increases in food establishments and outlets numbers, inadequate knowledge in food handlers, lack of clean water, use of untreated human and animal waste in agriculture, suboptimal refrigeration, and poor personal hygiene (Käferstein et al., 1997).

Salmonella, Campylobacter, Enterohemorrhagic E. coli (EHEC) and Listeria are among the most common bacterial pathogens 


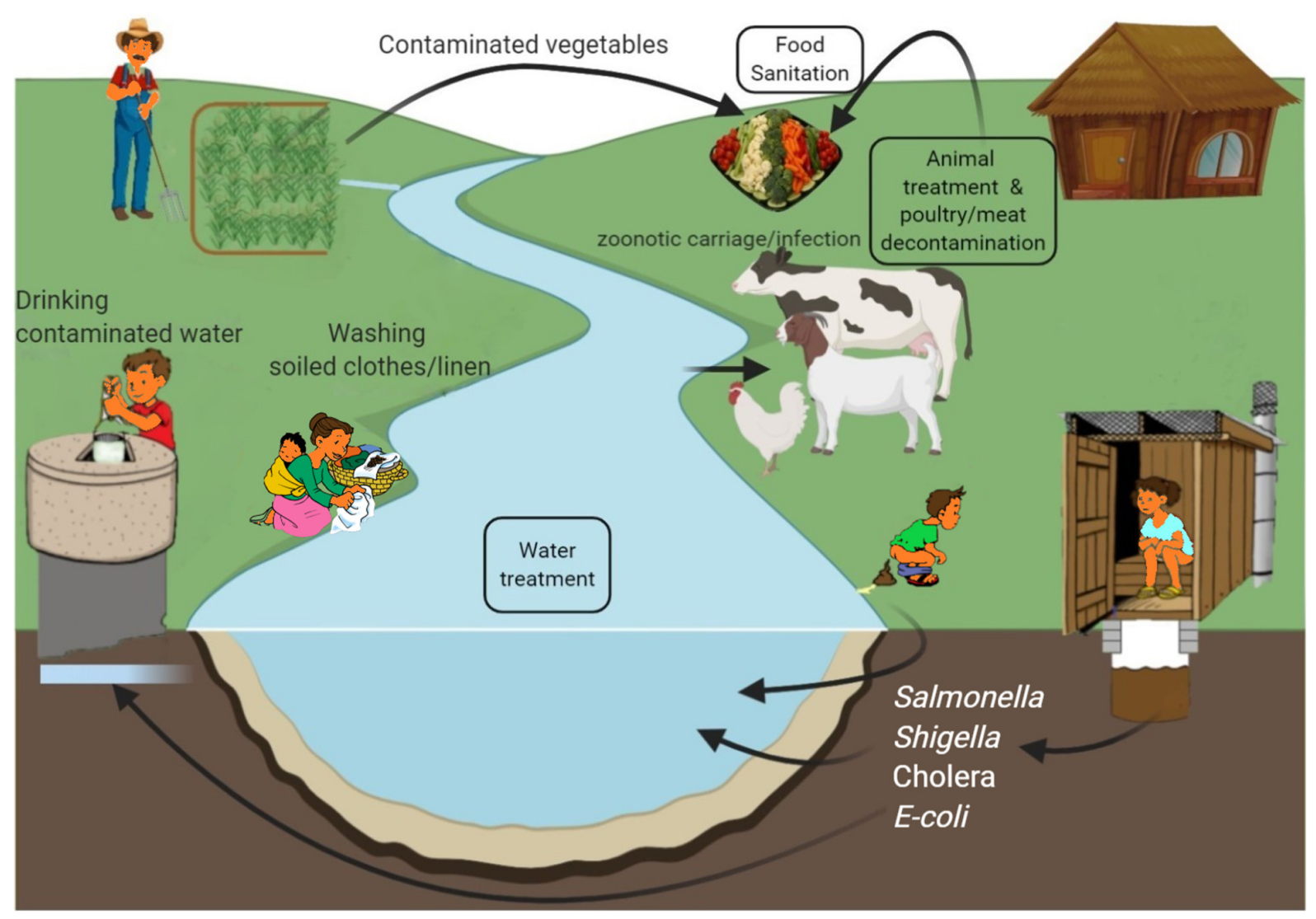

FIGURE 3 | Environmental sources of common bacterial infections in developing countries and possible phage interventions (boxed text) as preventive measure.

implicated in FBD (Havelaar et al., 2015). Multiple interventions are used to reduce contamination of foods with biological pathogens (Vikram et al., 2020) but all have limitations. There is an increased need for "natural" antimicrobial alternatives for food decontamination and preservation and many studies have established the usefulness of phages, including decontamination of processing surfaces (Moye et al., 2018). In addition to the appeal as an "organic" choice, phages have the advantages of high specificity, self-replication, co-evolution with their bacterial hosts, low toxicity, relatively inexpensive manufacturing and high tolerance of the conditions common in food processing and storage (Sillankorva et al., 2012).

Phages have long been recognized as a normal part of the food ecosystem (Whitman and Marshall, 1971; Hudson et al., 2005). Listeria monocytogenes, often associated with fresh or minimally processed foods such as dairy products and salads, was an early target for food sanitization attempts and their effectiveness in food products is well described (Amy Strydom, 2015). The first commercial phage biocontrol application against Listeria contamination for food safety was approved by FDA in 2006 (ListShield ${ }^{\mathrm{TM}}$ ) and a Generally Recognized as Safe (GRAS) designation was issued to another Listeria-specific phage biocontrol product (Listex ${ }^{\mathrm{TM}}$ ) later that same year. Since then, many other phage applications have been introduced into the market successfully (Vikram et al., 2020) and other pathogens such as Campylobacter may soon follow (Sillankorva et al., 2012). There are approved food safety phage applications against Salmonella, enterohaemorrhagic E-coli and Shigella (Moye et al., 2018), which constitute the majority of foodborne diseases of bacterial origin. Food sanitation by phage biocontrol should remain a high priority research and development agenda.

\section{Tuberculosis}

Tuberculosis (TB) is an airborne infectious disease caused by Mycobacterium tuberculosis complex. It is primarily a disease of the lungs but can disseminate to affect other parts of the body. TB is a leading cause of global mortality and the highest among all infectious diseases, including HIV/AIDS. WHO reported an estimated 10 million new cases of TB with 1.2 million deaths in HIV-negative people and more than 250,000 deaths among HIV-positive people in 2018 (WHO, 2019). Developing countries account for more than two thirds of the global incidence of TB, with most high-income countries reporting less than 10 cases per 100,000 population annually compared to $150-$ 400 incident cases per 100,000 in high TB burden countries (WHO, 2019). Malnutrition, crowded living and work conditions and a lack of access to diagnosis and treatment contribute to a continued high disease burden in poor countries (Lonnroth et al., 2009). TB incidence is declining slowly at $1.6 \%$ per year globally but isoniazid and now rifampicin-resistant TB is 
increasingly reported (GBD Tuberculosis Collaboratoras, 2018) and the WHO's "End TB Strategy" target of $>4 \%$ sustained annual decline in incidence of new cases by 2,030 seems unlikely to be met (Furin et al., 2019).

Effective antimicrobial treatment for TB typically includes at least an intensive initial 2 months of therapy with four firstline drugs (isoniazid, rifampicin, pyrazinamide, and ethambutol) followed by continuation phase with isoniazid and rifampicin for 4 months (Nahid et al., 2016; WHO, 2017b), the efficacy of which is usually monitored with repeated sputum smears, cultures and chest X-rays. Drug toxicity is not uncommon and the duration of therapy makes compliance difficult (Pai et al., 2016). MDR TB is steadily increasing in endemic countries (Dheda et al., 2017) and the emergence of extremely drug resistant TB (XDR-TB), for which there is almost no effective treatment, creates a pool of patients actively transmitting untreatable strains (Pietersen et al., 2014). The Bacillus Calmette-Guerin (BCG) vaccine is used worldwide mainly to prevent life-threatening tuberculosis in infants and young adults but is not an effective eradication strategy (Abubakar et al., 2013). There are other candidate vaccines in development with better efficacy profile in newborns and children, as well as adolescents and adults (Pai et al., 2016), but none are widely available.

There is considerable interest in mycobacteriophages for treatment and control of TB. They have been tested against MDR and XDR strains (Hatfull, 2014) but early animal studies met with mixed results (Mankiewicz and Beland, 1964; Sula et al., 1981) and there are no human trials as yet. some benefits were observed in guinea pigs with disseminated TB (Zemskova and Dorozhkova, 1991) but there are concerns regarding phage penetration to attack intracellular bacilli or those deep within granulomatous lesions (Hatfull, 2014). Use of non-virulent bacteria to deliver phage payloads into macrophages led to a significant reduction in viable intracellular bacilli in experimental animals (Broxmeyer et al., 2002) but the clinical applicability of this approach needs further evaluation.

Prospects for phage prophylaxis of TB contacts may be better. Inhaled bacilli from exposure should be easily accessible to phages introduced directly into the lungs in high concentrations, perhaps reducing risk of resistance evolution among small populations of targeted bacteria (Vehring, 2016) and this approach appeared to reduce the pulmonary MTB burden in mice up to 3 weeks after challenge (Carrigy et al., 2019). Aerosolised phage delivery into the lungs may be the optimal route (reviewed by Abedon, 2015) but particle diameter and tolerance of physical, osmotic and thermal stress are important considerations (Hoe et al., 2013).

The natural course of $\mathrm{TB}$ is indolent and subclinical with most disease transmission in high-burden countries unrecognized until recrudescent (secondary) disease develops, often decades later. Phage therapy may have value as a prophylactic regimen in recent exposure populations but studies would probably need to be randomized as adjunctive therapy (with standard agents) and surrogate (e.g., serological) markers may be needed to avoid decades of follow-up. Phage prophylaxis and therapy may be most valuable in severe and/or XDR-TB where need is urgent and response relatively easily measured.

\section{DISCUSSION}

Phage therapy is increasingly re-emerging as a viable therapeutic option against serious bacterial infections. Notwithstanding the long experience in parts of Europe and the numerous anecdotes of successful phage therapy for human infection (d'Herelle, 1931; Summers, 2001; Abedon et al., 2011; McCallin and Brüssow, 2017; Gordillo Altamirano and Barr, 2019), it remains poorly accepted in Western medicine.

Recently, there has been a noticeable increase in compassionate use of phage therapy to treat serious bacterial infections and the results are promising (Maddocks et al., 2019; Aslam et al., 2020; Cano et al., 2020; Petrovic Fabijan et al., 2020b). However, robust clinical trials are very few and mostly unsuccessful (Sarker et al., 2016; Jault et al., 2019; Leitner et al., 2020).

There are some important challenges to the progress of phage therapy through the existing regulatory frameworks, most prominent being the scarcity of essential data from human therapy. Phage(s) selection, optimal route of administration and dosage, the relative benefit of single vs. multiple phages and/or combinations with antibiotics all remain as questions that have yet to be decided. Pharmacokinetic and pharmacodynamic properties are generally regarded as unpredictable and must be better defined (Nilsson, 2019). The in vivo coevolution of phages and their target bacteria and the potential interference of human immune system further complicate phage therapy, and the fact that compassionate use cases typically utilize phage/s as adjuvants to antibiotic/s makes it more difficult to attribute efficacy. The emergence of phageresistant bacteria may be countered by using multiple effective phages in a cocktail (Pirnay and Kutter, 2020) and this popular approach means that complex multi-phage dynamics must also to be considered.

Oral administration is an appealing option, especially for enteric diseases, with the key advantage of greater simplicity of manufacture. Safety of phage therapy has been well demonstrated for suitable preparations but oral bioavailability and dosing kinetics are not well understood (Bruttin and Brussow, 2005; Sarker et al., 2017; Petrovic Fabijan et al., 2020b). The limited data that are available suggest that bioavailability may be adequate for oral dosing in animals (Watanabe et al., 2007; Miedzybrodzki et al., 2017) and humans (Weber-Dabrowska et al., 1987).

Aerosol delivery of phages into lungs is also relatively simple (Abedon, 2015; Maddocks et al., 2019) but GMP-grade preparation for nebulization (as for IV administration) remains a financial and logistical challenge.

Much of the current demand for phages to treat major developing country diseases relies on goodwill to meet it. Organizations such as "Phages for Global Health" raise awareness and educate/train laboratory and healthcare staff and build capacity in developing countries while biotech ventures such as "PhagePro" work to develop phage-based products to treat cholera.

The willingness of phage laboratories in developed countries to donate therapeutic candidate phages are a boon for physicians in developing countries and organizations such as 
Phage Directory ${ }^{1}$ work to facilitate access to these but a sustainable approach must be developed.

Coordinated efforts are needed from international health organizations to properly evaluate the potential role of phage therapy and identify potential candidates for properly designed trials.

\section{AUTHOR CONTRIBUTIONS}

AK, RCYL, and JRI conceived and drafted the manuscript. All authors read and approved the final manuscript.

${ }^{1}$ https://phage.directory/

\section{REFERENCES}

Aarestrup, F. (2012). Sustainable farming: Get pigs off antibiotics. Nature 486, 465-466. doi: 10.1038/486465a

Abedon, S. T. (2015). Phage therapy of pulmonary infections. Bacteriophage 5:e1020260. doi: 10.1080/21597081.2015.1020260

Abedon, S. T., Kuhl, S. J., Blasdel, B. G., and Kutter, E. M. (2011). Phage treatment of human infections. Bacteriophage 1, 66-85. doi: 10.4161/bact.1.2. 15845

Abubakar, I., Pimpin, L., Ariti, C., Beynon, R., Mangtani, P., Sterne, J. A., et al. (2013). Systematic review and meta-analysis of the current evidence on the duration of protection by bacillus Calmette-Guerin vaccination against tuberculosis. Health Technol. Assess. 17, 1-372.doi: 10.3310/hta17370

Aggarwal, P., Uppal, B., Ghosh, R., Krishna Prakash, S., Chakravarti, A., Jha, A. K., et al. (2016). Multi drug resistance and Extended Spectrum Beta Lactamases in clinical isolates of Shigella: A study from New Delhi, India. Travel Med. Infect. Dis. 14, 407-413. doi: 10.1016/j.tmaid.2016.05.006

Ahmed, A. M., and Shimamoto, T. (2015). Molecular characterization of multidrug-resistant Shigella spp. of food origin. Int. J. Food Microbiol. 194, 78-82. doi: 10.1016/j.ijfoodmicro.2014.11.013

Akinyemi, K. O., Iwalokun, B. A., Alafe, O. O., Mudashiru, S. A., and Fakorede, C. (2015). bla CTX-M-I group extended spectrum beta lactamase-producing Salmonella typhi from hospitalized patients in Lagos, Nigeria. Infect. Drug Resist. 8, 99-106. doi: 10.2147/idr.s78876

Alanis, A. J. (2005). Resistance to antibiotics: are we in the post-antibiotic era? Arch. Med. Res. 36, 697-705. doi: 10.1016/j.arcmed.2005.06.009

Ali, M., Nelson, A. R., Lopez, A. L., and Sack, D. A. (2015). Updated global burden of cholera in endemic countries. PLoS Negl. Trop Dis. 9:e0003832. doi: 10.1371 /journal.pntd.0003832

Amy Strydom, C. R. W. (2015). Listeria monocytogenes: A Target for Bacteriophage Biocontrol. Comprehen. Rev. Food Sci. Food Safety 14, 694-704. doi: 10.1111/1541-4337.12153

Anpilov, L. I., and Prokudin, A. A. (1984). Preventive effectiveness of dried polyvalent Shigella bacteriophage in organized collective farms. Voen Med. Zh. $5,39-40$.

Aslam, S., Lampley, E., Wooten, D., Karris, M., Benson, C., Strathdee, S., et al. (2020). Lessons Learned From the First 10 Consecutive Cases of Intravenous Bacteriophage Therapy to Treat Multidrug-Resistant Bacterial Infections at a Single Center in the United States. Open Forum Infect. Dis. 7:ofaa389. doi: 10.1093/ofid/ofaa389

Ayukekbong, J. A., Ntemgwa, M., and Atabe, A. N. (2017). The threat of antimicrobial resistance in developing countries: causes and control strategies. Antimicrob. Resist. Infect. Control. 6:47. doi: 10.1186/s13756-017-0208-x

Azmi, I. J., Khajanchi, B. K., Akter, F., Hasan, T. N., Shahnaij, M., Akter, M., et al. (2014). Fluoroquinolone resistance mechanisms of Shigella flexneri isolated in Bangladesh. PLoS One 9:e102533. doi: 10.1371/journal.pone.0102533

Babalova, E. G., Katsitadze, K. T., Sakvarelidze, L. A., Imnaishvili, N., Sharashidze, T. G., Badashvili, V. A., et al. (1968). [Preventive value of dried dysentery bacteriophage]. Zh Mikrobiol. Epidemiol. Immunobiol. 45, $143-145$.

\section{FUNDING}

Publication costs were covered by the Westmead Institute for Medical Research, Sydney, Australia.

\section{ACKNOWLEDGMENTS}

This manuscript is a result of collective interactions with many fellow clinicians and researchers specifically AK: Pakistan, Saudi Arabia and JRI: Australia, United Kingdom, U.S., Germany, and Phage network (RCYL and JRI), Denmark, South Korea, Israel, U.S., and Belgium.

Baker, K. S., Dallman, T. J., Field, N., Childs, T., Mitchell, H., Day, M., et al. (2018). Genomic epidemiology of Shigella in the United Kingdom shows transmission of pathogen sublineages and determinants of antimicrobial resistance. Sci. Rep. 8:7389. doi: 10.1038/s41598-018-25764-3

Bhandare, S., Colom, J., Baig, A., Ritchie, J. M., Bukhari, H., Shah, M. A., et al. (2019). Reviving Phage Therapy for the Treatment of Cholera. J. Infect. Dis. 219, 786-794. doi: 10.1093/infdis/jiy563

Bhutta, Z. A., Sommerfeld, J., Lassi, Z. S., Salam, R. A., and Das, J. K. (2014). Global burden, distribution, and interventions for infectious diseases of poverty. Infect. Dis. Poverty 3:21. doi: 10.1186/2049-9957-3-21

Broxmeyer, L., Sosnowska, D., Miltner, E., Chacon, O., Wagner, D., McGarvey, J., et al. (2002). Killing of Mycobacterium avium and Mycobacterium tuberculosis by a mycobacteriophage delivered by a nonvirulent mycobacterium: a model for phage therapy of intracellular bacterial pathogens. J. Infect. Dis. 186, 1155-1160. doi: $10.1086 / 343812$

Brussow, H. (2019). Hurdles for Phage Therapy to Become a Reality-An Editorial Comment. Viruses 11:557. doi: 10.3390/v11060557

Bruttin, A., and Brussow, H. (2005). Human volunteers receiving Escherichia coli phage T4 orally: a safety test of phage therapy. Antimicrob. Agents Chemother. 49, 2874-2878. doi: 10.1128/aac.49.7.2874-2878.2005

Cano, E. J., Caflisch, K. M., Bollyky, P. L., Van Belleghem, J. D., Patel, R., Fackler, J., et al. (2020). Phage Therapy for Limb-threatening Prosthetic Knee Klebsiella pneumoniae Infection: Case Report and In Vitro Characterization of Anti-biofilm Activity. Clin Infect Dis. 2020:705. doi: 10.1093/cid/ ciaa705

Carrigy, N. B., Larsen, S. E., Reese, V., Pecor, T., Harrison, M., Kuehl, P. J., et al. (2019). Prophylaxis of Mycobacterium tuberculosis H37Rv Infection in a Preclinical Mouse Model via Inhalation of Nebulized Bacteriophage D29. Antimicrob. Agents Chemother. 63:e00871-19. doi: 10.1128/AAC.00 871-19

CDC (2013). Antibiotic Resistance Threats in the United States, 2013. Federal government of the United States: CDC.

Chang, C. Y., Lu, P. L., Lin, C. C., Lee, T. M., Tsai, M. Y., and Chang, L. L. (2011). Integron types, gene cassettes, antimicrobial resistance genes and plasmids of Shigella sonnei isolates from outbreaks and sporadic cases in Taiwan. J. Med. Microbiol. 60(Pt 2), 197-204. doi: 10.1099/jmm.0.022517-0

Chanishvili, N. (2012). Phage therapy-history from Twort and d'Herelle through Soviet experience to current approaches. Adv. Virus Res. 83, 3-40. doi: 10.1016/ b978-0-12-394438-2.00001-3

Chatham-Stephens, K., Medalla, F., Hughes, M., Appiah, G. D., Aubert, R. D., Caidi, H., et al. (2019). Emergence of Extensively Drug-Resistant Salmonella Typhi Infections Among Travelers to or from Pakistan - United States, 20162018. MMWR Morb. Mortal Wkly Rep. 68, 11-13. doi: 10.15585/mmwr. mm6801a3

Chatterjee, P., Kanungo, S., Bhattacharya, S. K., and Dutta, S. (2020). Mapping cholera outbreaks and antibiotic resistant Vibrio cholerae in India: An assessment of existing data and a scoping review of the literature. Vaccine 38(Suppl. 1), A93-A104. doi: 10.1016/j.vaccine.2019.12.003

Chiou, C. S., Izumiya, H., Kawamura, M., Liao, Y. S., Su, Y. S., Wu, H. H., et al. (2016). The worldwide spread of ciprofloxacin-resistant Shigella sonnei among 
HIV-infected men who have sex with men, Taiwan. Clin. Microbiol. Infect. 31:e316. doi: 10.1016/j.cmi.2015.12.021

Chung The, H., Rabaa, M. A., Thanh, D. Pham, Lappe, N. De, Cormican, M., Valcanis, M., et al. (2016). South Asia as a Reservoir for the Global Spread of Ciprofloxacin-Resistant Shigella sonnei: A Cross-Sectional Study. PLoS Med. 13:e1002055. doi: 10.1371/journal.pmed.1002055

Cohen, D., Green, M., Block, C., Slepon, R., Ambar, R., Wasserman, S. S., et al. (1991). Reduction of transmission of shigellosis by control of houseflies (Musca domestica). Lancet 337, 993-997. doi: 10.1016/0140-6736(91)92657-n

Croxen, M. A., Law, R. J., Scholz, R., Keeney, K. M., Wlodarska, M., and Finlay, B. B. (2013). Recent advances in understanding enteric pathogenic Escherichia coli. Clin. Microbiol. Rev. 26, 822-880. doi: 10.1128/cmr.00022-13

d'Herelle, F. (1929). Studies Upon Asiatic Cholera. Yale J. Biol. Med. 1, 195-219.

d'Herelle, F. (1931). Bacteriophage as a Treatment in Acute Medical and Surgical Infections. Bull N Y Acad. Med. 7, 329-348.

Darsley, M. J., Chakraborty, S., DeNearing, B., Sack, D. A., Feller, A., Buchwaldt, C., et al. (2012). The oral, live attenuated enterotoxigenic Escherichia coli vaccine ACE527 reduces the incidence and severity of diarrhea in a human challenge model of diarrheal disease. Clin. Vaccine Immunol. 19, 1921-1931. doi: 10.1128/ cvi.00364- 12

Dengo-Baloi, L. C., Sema-Baltazar, C. A., Manhique, L. V., Chitio, J. E., Inguane, D. L., and Langa, J. P. (2017). Antibiotics resistance in El Tor Vibrio cholerae 01 isolated during cholera outbreaks in Mozambique from 2012 to 2015. PLoS One 12:e0181496. doi: 10.1371/journal.pone.0181496

Desranleau, J. M. (1948). The treatment of typhoid fever by the use of Vi antityphoid bacteriophages; a preliminary report. Can. J. Public Health 39, 317-319.

Desranleau, J. M. (1949). Progress in the treatment of typhoid fever with Vi bacteriophages. Can. J. Public Health 40, 473-478.

Dheda, K., Gumbo, T., Maartens, G., Dooley, K. E., McNerney, R., Murray, M., et al. (2017). The epidemiology, pathogenesis, transmission, diagnosis, and management of multidrug-resistant, extensively drug-resistant, and incurable tuberculosis. Lancet Respir. Med. 2017:2600(17)30079-6.

Doore, S. M., Schrad, J. R., Dean, W. F., Dover, J. A., and Parent, K. N. (2018). Shigella Phages Isolated during a Dysentery Outbreak Reveal Uncommon Structures and Broad Species Diversity. J. Virol. 92:e02117-17.doi: 10.1128/JVI. 02117- 17

Dubos, R. J., Straus, J. H., and Pierce, C. (1943). The Multiplication of Bacteriophage in Vivo and Its Protective Effect against an Experimental Infection with Shigella dysenteriae. J. Exp. Med. 78, 161-168. doi: 10.1084/jem. 78.3.161

DuPont, H. L., Levine, M. M., Hornick, R. B., and Formal, S. B. (1989). Inoculum size in shigellosis and implications for expected mode of transmission. J. Infect. Dis. 159, 1126-1128. doi: 10.1093/infdis/159.6.1126

Engsbro, A. L., Riis Jespersen, H. S., Goldschmidt, M. I., Mollerup, S., Worning, P., Pedersen, M. S., et al. (2019). Ceftriaxone-resistant Salmonella enterica serotype Typhi in a pregnant traveller returning from Karachi, Pakistan to Denmark, 2019. Euro. Surveill. 24:1900289.doi: 10.2807/1560-7917.ES.2019.24. 21.1900289

Faruque, S. M. I, Naser, B., Islam, M. J., Faruque, A. S., Ghosh, A. N., Nair, G. B., et al. (2005). Seasonal epidemics of cholera inversely correlate with the prevalence of environmental cholera phages. Proc. Natl. Acad. Sci. U S A 102, 1702-1707. doi: 10.1073/pnas.0408992102

Furin, J., Cox, H., and Pai, M. (2019). Tuberculosis. Lancet 393, 1642-1656.

Ganesan, D., Gupta, S. S., and Legros, D. (2020). Cholera surveillance and estimation of burden of cholera. Vaccine 38(Suppl. 1), A13-A17. doi: 10.1016/j. vaccine.2019.07.036

GBD Causes of Death Collaborators. (2018). Global, regional, and national agesex-specific mortality for 282 causes of death in 195 countries and territories, 1980-2017: a systematic analysis for the Global Burden of Disease Study 2017. Lancet 392, 1736-1788.doi: 10.1016/S0140-6736(18)32203-7

Tuberculosis, G. B. D., and Collaborators. (2018). The global burden of tuberculosis: results from the Global Burden of Disease Study 2015. Lancet Infect. Dis. 18, 261-284. doi: 10.1016/S1473-3099(17)30703-X

GebreSilasie, Y. M., Tullu, K. D., and Yeshanew, A. G. (2018). Resistance pattern and maternal knowledge, attitude and practices of suspected Diarrheagenic Escherichia coli among children under 5 years of age in Addis Ababa, Ethiopia: cross sectional study. Antimicrob. Resist. Infect. Control. 7:110. doi: 10.1186/ s13756-018-0402-5

Gill, J. J., and Hyman, P. (2010). Phage choice, isolation, and preparation for phage therapy. Curr. Pharm. Biotechnol. 11, 2-14. doi: 10.2174/1389201107907 25311

Goodridge, L. D. (2013). Bacteriophages for managing Shigella in various clinical and non-clinical settings. Bacteriophage 3:e25098. doi: 10.4161/bact.25098

Gordillo Altamirano, F. L., and Barr, J. J. (2019). Phage Therapy in the Postantibiotic Era. Clin. Microb. Rev. 32:00066-18.doi: 10.1128/CMR.00066-18

Grace, D. (2015). Food Safety in Developing Countries: An Overview. Evidence on Demand, UK: Food Safety in Developing Countries.

Gregory, A., Roth, D. A., Kalkidan, H. A., and Solomon, M. A. (2018). Global, regional, and national age-sex-specific mortality for 282 causes of death in 195 countries and territories, 1980-2017: a systematic analysis for the Global Burden of Disease Study 2017. Lancet 392, 1736-1788.

Gu, B., Cao, Y., Pan, S., Zhuang, L., Yu, R., Peng, Z., et al. (2012). Comparison of the prevalence and changing resistance to nalidixic acid and ciprofloxacin of Shigella between Europe-America and Asia-Africa from 1998 to 2009. Int. J. Antimicrob. Agents 40, 9-17. doi: 10.1016/j.ijantimicag.2012.02.005

Gupta, P. K., Pant, N. D., Bhandari, R., and Shrestha, P. (2016). Cholera outbreak caused by drug resistant Vibrio cholerae serogroup O1 biotype ElTor serotype Ogawa in Nepal; a cross-sectional study. Antimicrob. Resist. Infect. Control 5:23. doi: 10.1186/s13756-016-0122-7

Harris, J. B., LaRocque, R. C., Qadri, F., Ryan, E. T., and Calderwood, S. B. (2012). Cholera. Lancet 379, 2466-2476. doi: 10.1016/S0140-6736(12)60436-X

Harro, C., Louis Bourgeois, A., Sack, D., Walker, R., DeNearing, B., Brubaker, J., et al. (2019). Live attenuated enterotoxigenic Escherichia coli (ETEC) vaccine with dmLT adjuvant protects human volunteers against virulent experimental ETEC challenge. Vaccine 37, 1978-1986. doi: 10.1016/j.vaccine.2019. 02.025

Hatfull, G. F. (2014). Molecular Genetics of Mycobacteriophages. Microbiol. Spectr. 2, 1-36. doi: 10.1128/microbiolspec.MGM2-0032-2013

Hatfull, G. F. (2014). Mycobacteriophages: windows into tuberculosis. PLoS Pathog. 10:e1003953. doi: 10.1371/journal.ppat.1003953

Havelaar, A. H., Kirk, M. D., Torgerson, P. R., Gibb, H. J., Hald, T., Lake, R. J., et al. (2015). World Health Organization Global Estimates and Regional Comparisons of the Burden of Foodborne Disease in 2010. PLoS Med. 12:e1001923. doi: 10.1371/journal.pmed.1001923

Heiman, K. E., Karlsson, M., Grass, J., Howie, B., Kirkcaldy, R. D., Mahon, B., et al. (2014). Notes from the field: Shigella with decreased susceptibility to azithromycin among men who have sex with men - United States, 2002-2013. MMWR Morb. Mortal. Wkly Rep. 63, 132-133.

Hoe, S., Semler, D. D., Goudie, A. D., Lynch, K. H., Matinkhoo, S., Finlay, W. H., et al. (2013). Respirable bacteriophages for the treatment of bacterial lung infections. J. Aerosol. Med. Pulm. Drug Deliv. 26, 317-335. doi: 10.1089/jamp. 2012.1001

Houpt, E. R., Ferdous, T., Ara, R., Ibrahim, M., Alam, M. M., Kabir, M., et al. (2020). Clinical outcomes of drug-resistant shigellosis treated with azithromycin in Bangladesh. Clin. Infect. Dis. 2020:ciaa363.doi: 10.1093/cid/ciaa363

Howard-Jones, A., Kesson, A. M., Outhred, A. C., and Britton, P. N. (2019). First reported case of extensively drug-resistant typhoid in Australia. Med. J. Aust. 28:e281. doi: 10.5694/mja2.50316

Hudson, J. A., Billington, C., Carey-Smith, G., and Greening, G. (2005). Bacteriophages as biocontrol agents in food. J. Food Prot. 68, 426-437. doi: 10.4315/0362-028x-68.2.426

Hussen, S., Mulatu, G., and Yohannes Kassa, Z. (2019). Prevalence of Shigella species and its drug resistance pattern in Ethiopia: a systematic review and meta-analysis. Ann. Clin. Microbiol. Antimicrob. 18:22. doi: 10.1186/s12941019-0321-1

Jaiswal, A., Koley, H., Ghosh, A., Palit, A., and Sarkar, B. (2013). Efficacy of cocktail phage therapy in treating Vibrio cholerae infection in rabbit model. Microb. Infect. 15, 152-156. doi: 10.1016/j.micinf.2012.11.002

Jault, P., Leclerc, T., Jennes, S., Pirnay, J. P., Que, Y. A., Resch, G., et al. (2019) Efficacy and tolerability of a cocktail of bacteriophages to treat burn wounds infected by Pseudomonas aeruginosa (PhagoBurn): a randomised, controlled, double-blind phase 1/2 trial. Lancet Infect. Dis. 19, 35-45. doi: 10.1016/s14733099(18)30482-1 
Jun, J. W., Giri, S. S., Kim, H. J., Yun, S. K., Chi, C., Chai, J. Y., et al. (2016). Bacteriophage application to control the contaminated water with Shigella. Sci. Rep. 6:22636. doi: 10.1038/srep22636

Käferstein, F. K. (2003). FOOD SAFETY IN FOOD SECURITY AND FOOD TRADE: Food Safety as a Public Health Issue for Developing Countries." 2020 vision briefs 10 No. 2, International Food Policy Research Institute (IFPRI). RePEc:fpr:2020br:1002. Washington, D.C: International Food Policy Research Institute

Käferstein, F. K., Motarjemi, Y., and Bettcher, D. W. (1997). Foodborne disease control: a transnational challenge. Emerg. Infect. Dis. 3, 503-510. doi: 10.3201/ eid0304.970414

Kakabadze, E., Makalatia, K., Grdzelishvili, N., Bakuradze, N., Goderdzishvili, M., Kusradze, I., et al. (2018). Selection of Potential Therapeutic Bacteriophages that Lyse a CTX-M-15 Extended Spectrum beta-Lactamase Producing Salmonella enterica Serovar Typhi Strain from the Democratic Republic of the Congo. Viruses 10:2018.doi: 10.3390/v10040172

Khalil, I. A., Troeger, C., Blacker, B. F., Rao, P. C., Brown, A., Atherly, D. E., et al. (2018). Morbidity and mortality due to shigella and enterotoxigenic Escherichia coli diarrhoea: the Global Burden of Disease Study 1990-2016. Lancet Infect. Dis. 18, 1229-1240. doi: 10.1016/S1473-3099(18)30475-4

Khan, W. A., Griffiths, J. K., and Bennish, M. L. (2013). Gastrointestinal and extraintestinal manifestations of childhood shigellosis in a region where all four species of Shigella are endemic. PLoS One 8:e64097. doi: 10.1371/journal.pone. 0064097

Kleine, C. E., Schlabe, S., Hischebeth, G. T. R., Molitor, E., Pfeifer, Y., Wasmuth, J. C., et al. (2017). Successful Therapy of a Multidrug-Resistant ExtendedSpectrum beta-Lactamase-Producing and Fluoroquinolone-Resistant Salmonella enterica Subspecies enterica Serovar Typhi Infection Using Combination Therapy of Meropenem and Fosfomycin. Clin. Infect. Dis. 65, 1754-1756. doi: 10.1093/cid/cix652

Klemm, E. J., Shakoor, S., Page, A. J., Qamar, F. N., Judge, K., Saeed, D. K., et al. (2018). Emergence of an Extensively Drug-Resistant Salmonella enterica Serovar Typhi Clone Harboring a Promiscuous Plasmid Encoding Resistance to Fluoroquinolones and Third-Generation Cephalosporins. mBio 9:2018.doi: 10.1128/mBio.00105-18

Knouf, E. G., Ward, W. E., and Reichlea, P. A. (1946). Treatment of typhoid fever with type specific bacteriophage. J. Am. Med. Assoc. 132, 134-138. doi: 10.1001/jama.1946.02870380016006

Kotloff, K. L., Winickoff, J. P., Ivanoff, B., Clemens, J. D., Swerdlow, D. L., Sansonetti, P. J., et al. (1999). Global burden of Shigella infections: implications for vaccine development and implementation of control strategies. Bull World Health Organ. 77, 651-666.

Laxminarayan, R., Duse, A., Wattal, C., Zaidi, A. K., Wertheim, H. F., Sumpradit, N., et al. (2013). Antibiotic resistance-the need for global solutions. Lancet Infect. Dis. 13, 1057-1098. doi: 10.1016/S1473-3099(13)70318-9

Leitner, L., Ujmajuridze, A., Chanishvili, N., Goderdzishvili, M., Chkonia, I., Rigvava, S., et al. (2020). Intravesical bacteriophages for treating urinary tract infections in patients undergoing transurethral resection of the prostate: a randomised, placebo-controlled, double-blind clinical trial. Lancet Infect. Dis. doi: 10.1016/S1473-3099(20)30330-3. [Epub ahead of print].

Llanos-Chea, A., Citorik, R. J., Nickerson, K. P., Ingano, L., Serena, G., Senger, S., et al. (2019). Bacteriophage Therapy Testing Against Shigella flexneri in a Novel Human Intestinal Organoid-Derived Infection Model. J. Pediatr. Gastroenterol. Nutr. 68, 509-516. doi: 10.1097/mpg.0000000000002203

Lonnroth, K., Jaramillo, E., Williams, B. G., Dye, C., and Raviglione, M. (2009). Drivers of tuberculosis epidemics: the role of risk factors and social determinants. Soc. Sci. Med. 68, 2240-2246. doi: 10.1016/j.socscimed.2009.03. 041

Lopez-Segura, N., Corbero-Rivali, C., Maldonado-Fernandez, M. C., Calpe-Fraile, S., Peyra-Ros, J., and Martinez-Roig, A. (2019). Imported extensively drug resistant typhoid fever in a child travelling to Spain from Pakistan. J. Travel. Med. 26.doi: $10.1093 / \mathrm{jtm} / \mathrm{taz} 066$

Maddocks, S., Fabijan, A. P., Ho, J., Lin, R. C. Y., Ben Zakour, N. L., Dugan, C., et al. (2019). Bacteriophage Therapy of Ventilator-associated Pneumonia and Empyema Caused by Pseudomonas aeruginosa. Am. J. Respir. Crit. Care Med. 200, 1179-1181. doi: 10.1164/rccm.201904-0839le

Mandomando, I., Jaintilal, D., Pons, M. J., Valles, X., Espasa, M., Mensa, L., et al. (2009). Antimicrobial susceptibility and mechanisms of resistance in Shigella and Salmonella isolates from children under five years of age with diarrhea in rural Mozambique. Antimicrob. Agents Chemother. 53, 2450-2454. doi: 10.1128/aac.01282-08

Mani, S., Wierzba, T., and Walker, R. I. (2016). Status of vaccine research and development for Shigella. Vaccine 34, 2887-2894. doi: 10.1016/j.vaccine.2016. 02.075

Mankiewicz, E., and Beland, J. (1964). The Role of Mycobacteriophages and of Cortisone in Experimental Tuberculosis and Sarcoidosis. Am. Rev. Respir. Dis. $89,707-720$.

Marcuk, L. M., Nikiforov, V. N., Scerbak, J. F., Levitov, T. A., Kotljarova, R. I., Naumsina, M. S., et al. (1971). Clinical studies of the use of bacteriophage in the treatment of cholera. Bull World Health Organ. 45, 77-83.

McCallin, S., and Brüssow, H. (2017). "Clinical trials of bacteriophage therapeutics," in Bacteriophages, eds D. Harper, S. Abedon, B. Burrowes, and M. McConville (Cham: Springer). doi: 10.1007/978-3-319-40598-8_38-1

Michaud, C. M. (2009). Global Burden of Infectious Diseases. Encyclop. Microb. 2009, 444-454. doi: 10.1016/b978-012373944-5.00185-1

Miedzybrodzki, R., Klak, M., Jonczyk-Matysiak, E., Bubak, B., Wojcik, A., Kaszowska, M., et al. (2017). Means to Facilitate the Overcoming of Gastric Juice Barrier by a Therapeutic Staphylococcal Bacteriophage A5/80. Front. Microbiol. 8:467. doi: 10.3389/fmicb.2017.00467

Mogasale, V., Maskery, B., Ochiai, R. L., Lee, J. S., Mogasale, V. V., Ramani, E., et al. (2014). Burden of typhoid fever in low-income and middle-income countries: a systematic, literature-based update with risk-factor adjustment. Lancet Glob. Health 2, e570-e580. doi: 10.1016/S2214-109X(14)70301-8

Monsur, K. A., Rahman, M. A., Huq, F., Islam, M. N., Northrup, R. S., and Hirschhorn, N. (1970). Effect of massive doses of bacteriophage on excretion of vibrios, duration of diarrhoea and output of stools in acute cases of cholera. Bull World Health Organ. 42, 723-732.

Morton, H. E., and Engley, F. B. (1945). The Protective Action of Dysentery Bacteriophage in Experimental Infections in Mice. J. Bacteriol. 49, 245-255. doi: 10.1128/jb.49.3.245-255.1945

Moye, Z. D., Woolston, J., and Sulakvelidze, A. (2018). Bacteriophage Applications for Food Production and Processing. Viruses 10:2018.doi: 10.3390/v10040205

Nagel, T. E., Chan, B. K., De Vos, D., El-Shibiny, A., Kang'ethe, E. K., Makumi, A., et al. (2016). The Developing World Urgently Needs Phages to Combat Pathogenic Bacteria. Front. Microbiol. 7:882. doi: 10.3389/fmicb.2016.00882

Nahid, P., Dorman, S. E., Alipanah, N., Barry, P. M., Brozek, J. L., Cattamanchi, A., et al. (2016). Official American Thoracic Society/Centers for Disease Control and Prevention/Infectious Diseases Society of America Clinical Practice Guidelines: Treatment of Drug-Susceptible Tuberculosis. Clin. Infect. Dis. 63, e147-e195. doi: 10.1093/cid/ciw566

Nguyen, T. V., Le, P. V., Le, C. H., and Weintraub, A. (2005). Antibiotic resistance in diarrheagenic Escherichia coli and Shigella strains isolated from children in Hanoi, Vietnam. Antimicrob. Agents Chemother. 49, 816-819. doi: 10.1128/aac. 49.2.816-819.2005

Nilsson, A. S. (2019). Pharmacological limitations of phage therapy. Ups J. Med. Sci. 124, 218-227. doi: 10.1080/03009734.2019.1688433

Nuesch-Inderbinen, M., Heini, N., Zurfluh, K., Althaus, D., Hachler, H., and Stephan, R. (2016). Shigella Antimicrobial Drug Resistance Mechanisms, 20042014. Emerg. Infect. Dis. 22, 1083-1085. doi: 10.3201/eid2206.152088

O'Neill, J. (2016). Tackling Drug-Resistant Infections Globally: Final Report And Recommendations. London: Government of the United Kingdom.

Ochiai, R. L., Acosta, C. J., Danovaro-Holliday, M. C., Baiqing, D., Bhattacharya, S. K., Agtini, M. D., et al. (2008). A study of typhoid fever in five Asian countries: disease burden and implications for controls. Bull World Health Organ. 86, 260-268. doi: 10.2471/blt.06.039818

Pai, M., Behr, M. A., Dowdy, D., Dheda, K., Divangahi, M., Boehme, C. C., et al. (2016). Tuberculosis. Nat. Rev. Dis. Primers 2:16076. doi: 10.1038/nrdp.2016.76

Petrovic Fabijan, A., Khalid, A., Maddocks, S., Ho, J., Gilbey, T., Sandaradura, I., et al. (2020a). Phage therapy for severe bacterial infections: a narrative review. Med. J. Aust. 212, 279-285. doi: 10.5694/mja2.50355

Petrovic Fabijan, A., Lin, R. C. Y., Ho, J., Maddocks, S., Zakour, N. L. Ben, and Iredell, J. R. (2020b). Safety of bacteriophage therapy in severe Staphylococcus aureus infection. Nat. Microbiol. 5, 465-472. doi: 10.1038/s41564-0190634-z

Phoba, M. F., Barbe, B., Lunguya, O., Masendu, L., Lulengwa, D., Dougan, G., et al. (2017). Salmonella enterica serovar Typhi Producing CTX-M-15 Extended 
Spectrum beta-Lactamase in the Democratic Republic of the Congo. Clin. Infect. Dis. 65, 1229-1231. doi: 10.1093/cid/cix342

Pietersen, E., Ignatius, E., Streicher, E. M., Mastrapa, B., Padanilam, X., Pooran, A., et al. (2014). Long-term outcomes of patients with extensively drug-resistant tuberculosis in South Africa: a cohort study. Lancet 383, 1230-1239. doi: $10.1016 / \mathrm{s} 0140-6736(13) 62675-6$

Pirnay, J. P., and Kutter, E. (2020). Bacteriophages: it's a medicine, Jim, but not as we know it. Lancet Infect. Dis..2020:S1473-3099(20)30464-3doi: 10.1016/S14733099(20)30464-3

Procaccianti, M., Motta, A., Giordani, S., Riscassi, S., Guidi, B., Ruffini, M., et al. (2020). First Case of Typhoid Fever due to Extensively Drug-resistant Salmonella enterica serovar Typhi in Italy. Pathogens 9:151. doi: 10.3390/ pathogens 9020151

Puzari, M., Sharma, M., and Chetia, P. (2018). Emergence of antibiotic resistant Shigella species: A matter of concern. J. Infect. Public Health 11, 451-454. doi: 10.1016/j.jiph.2017.09.025

Rijal, N., Acharya, J., Adhikari, S., Upadhaya, B. P., Shakya, G., Kansakar, P., et al. (2019). Changing epidemiology and antimicrobial resistance in Vibrio cholerae: AMR surveillance findings (2006-2016) from Nepal. BMC Infect Dis. 19:801. doi: 10.1186/s12879-019-4432-2

Rojas-Lopez, M., Monterio, R., Pizza, M., Desvaux, M., and Rosini, R. (2018). Intestinal Pathogenic Escherichia coli: Insights for Vaccine Development. Front. Microbiol. 9:440. doi: 10.3389/fmicb.2018.00440

Sarker, S. A., Berger, B., Deng, Y., Kieser, S., Foata, F., Moine, D., et al. (2017). Oral application of Escherichia coli bacteriophage: safety tests in healthy and diarrheal children from Bangladesh. Environ. Microbiol. 19, 237-250. doi: 10.1111/1462-2920.13574

Sarker, S. A., Sultana, S., Reuteler, G., Moine, D., Descombes, P., Charton, F., et al. (2016). Oral Phage Therapy of Acute Bacterial Diarrhea With Two Coliphage Preparations: A Randomized Trial in Children From Bangladesh. EBioMedicine 4, 124-137. doi: 10.1016/j.ebiom.2015.12.023

Sayamov, R. M. (1963). Treatment and prophylaxis of cholera with bacteriophage. Bull World Health Organ. 28, 361-367.

Seo, H., Duan, Q., and Zhang, W. (2020). Vaccines against gastroenteritis, current progress and challenges. Gut. Microbes 11, 1486-1517. doi: 10.1080/19490976. 2020.1770666

Shakya, M., Colin-Jones, R., Theiss-Nyland, K., Voysey, M., Pant, D., Smith, N., et al. (2019). Phase 3 Efficacy Analysis of a Typhoid Conjugate Vaccine Trial in Nepal. N. Engl. J. Med. 381, 2209-2218. doi: 10.1056/nejmoa19 05047

Sillankorva, S. M., Oliveira, H., and Azeredo, J. (2012). Bacteriophages and their role in food safety. Int. J. Microbiol. 2012:863945. doi: 10.1155/2012/863945

Silverman, E. (2020). Pharma giants to unveil major $\$ 1$ billion venture to push novel antibiotics. Boston: STAT.

Smith, H. W., and Huggins, M. B. (1982). Successful treatment of experimental Escherichia coli infections in mice using phage: its general superiority over antibiotics. J. Gen. Microbiol. 128, 307-318. doi: 10.1099/00221287-128-2-307

Smith, H. W., and Huggins, M. B. (1983). Effectiveness of phages in treating experimental Escherichia coli diarrhoea in calves, piglets and lambs. J. Gen. Microbiol. 129, 2659-2675. doi: 10.1099/00221287-129-8-2659

Smith, H. W., Huggins, M. B., and Shaw, K. M. (1987). The control of experimental Escherichia coli diarrhoea in calves by means of bacteriophages. J. Gen. Microbiol. 133, 1111-1126. doi: 10.1099/00221287-133-5-1111

Smith, J. (1924). The Bacteriophage in the Treatment of Typhoid Fever. Br. Med. J. 2, 47-49. doi: 10.1136/bmj.2.3315.47

Soffer, N., Woolston, J., Li, M., Das, C., and Sulakvelidze, A. (2017). Bacteriophage preparation lytic for Shigella significantly reduces Shigella sonnei contamination in various foods. PLoS One 12:e0175256. doi: 10.1371/journal.pone.0175256

Spencer, L., James, D., Global, A., Kalkidan, H. A., and Solomon, M. A. (2018). Global, regional, and national incidence, prevalence, and years lived with disability for 354 diseases and injuries for 195 countries and territories, 19902017: a systematic analysis for the Global Burden of Disease Study 2017. Lancet 392, 1789-1858.doi: 10.1016/S0140-6736(18)32279-7

Sula, L., Sulova, J., and Stolcpartova, M. (1981). Therapy of experimental tuberculosis in guinea pigs with mycobacterial phages DS-6A, GR-21 T, My-327. Czech Med. 4, 209-214.

Summers, W. C. (1993). Cholera and plague in India: the bacteriophage inquiry of 1927-1936. J. Hist. Med. Allied. Sci. 48, 275-301. doi: 10.1093/jhmas/48.3.275
Summers, W. C. (2001). Bacteriophage therapy. Annu. Rev. Microbiol. 55, 437-451. doi: 10.1146/annurev.micro.55.1.437

Tickell, K. D., Brander, R. L., Atlas, H. E., Pernica, J. M., Walson, J. L., and Pavlinac, P. B. (2017). Identification and management of Shigella infection in children with diarrhoea: a systematic review and meta-analysis. Lancet Glob. Health 5, e1235-e1248. doi: 10.1016/S2214-109X(17)30392-3

Tong, A. (2020). Pharma giants return to antibiotics huddle to launch $\$ 1 B$ venture fund. Endpoint News. https://endpts.com/pharma-giants-returnto-antibiotics-huddle-to-launch-1b-venture-fund-report/.(accessed date: June 29, 2020)

Vehring, G. F. H. R. (2016). Respirable Bacteriophage Aerosols for the Prevention and Treatment of Tuberculosis. Hoboken, $\mathrm{N}$ J: Wiley.

Verma, J., Bag, S., Saha, B., Kumar, P., Ghosh, T. S., Dayal, M., et al. (2019). Genomic plasticity associated with antimicrobial resistance in Vibrio cholerae. Proc. Natl. Acad. Sci. U S A 116, 6226-6231. doi: 10.1073/pnas. 1900141116

Vikram, A., Woolston, J., and Sulakvelidze, A. (2020). Phage Biocontrol Applications in Food Production and Processing. Curr. Issues Mol. Biol. 40, 267-302. doi: 10.21775/cimb.040.267

Walker, R. I. (2015). An assessment of enterotoxigenic Escherichia coli and Shigella vaccine candidates for infants and children. Vaccine 33, 954-965. doi: 10.1016/ j.vaccine.2014.11.049

Wang, Y., Ma, Q., Hao, R., Zhang, Q., Yao, S., Han, J., et al. (2019). Antimicrobial resistance and genetic characterization of Shigella spp. in Shanxi Province, China, during 2006-2016. BMC Microbiol. 19:116. doi: 10.1186/s12866-0191495-6

Watanabe, R., Matsumoto, T., Sano, G., Ishii, Y., Tateda, K., Sumiyama, Y., et al. (2007). Efficacy of bacteriophage therapy against gut-derived sepsis caused by Pseudomonas aeruginosa in mice. Antimicrob. Agents Chemother. 51, 446-452. doi: $10.1128 /$ aac. $00635-06$

Weber-Dabrowska, B., Dabrowski, M., and Slopek, S. (1987). Studies on bacteriophage penetration in patients subjected to phage therapy. Arch. Immunol. Ther. Exp. 35, 563-568.

Whitman, P. A., and Marshall, R. T. (1971). Isolation of psychrophilic bacteriophage-host systems from refrigerated food products. Appl. Microbiol. 22, 220-223. doi: 10.1128/aem.22.2.220-223.1971

WHO (2005a). Guidelines for the control of shigellosis, including epidemics due to Shigella dysenteriae type 1. Geneva: WHO.

WHO (2005b). THE TREATMENT OF DIARRHOEA A manual for physicians and other senior health workers. Geneva: WHO.

WHO (2014). Antimicrobial Resistance Global Report on Surveillance. Geneva: WHO.

WHO (2015). "WHO Estimates of the Global Burden of Foodborne Diseases: Food borne disease burden epidemiology reference group 2007-2015. Geneva: WHO.

WHO (2017a). Cholera vaccines: WHO position paper - August 2017. Wkly Epidemiol. Rec. 92, 477-498.

WHO (2017b). Guidelines for treatment of drug-susceptible tuberculosis and patient care, 2017 update. Geneva: WHO.

WHO (2018). Cholera, 2018. Wkly Epidemiol. Rec. 94, 561-580.

WHO (2019). Global tuberculosis report 2019. Geneva: WHO.

Williams, P. C. M., and Berkley, J. A. (2018). Guidelines for the treatment of dysentery (shigellosis): a systematic review of the evidence. Paediatr. Int. Child Health 38, S50-S65. doi: 10.1080/20469047.2017.14 09454

Wong, W., Rawahi, H. A., Patel, S., Yau, Y., Eshaghi, A., Zittermann, S., et al. (2019). The first Canadian pediatric case of extensively drug-resistant Salmonella Typhi originating from an outbreak in Pakistan and its implication for empiric antimicrobial choices. IDCases 15:e00492. doi: 10.1016/j.idcr.2019.e0 0492

World Bank Group (2018). The Safe Food Imperative: Accelerating Progress in Lowand Middle-income Countries. Washington, D.C: World Bank Group.

Yen, M., Cairns, L. S., and Camilli, A. (2017). A cocktail of three virulent bacteriophages prevents Vibrio cholerae infection in animal models. Nat. Commun. 8:14187. doi: 10.1038/ncomms14187

Zaman, K., Ryun Kim, D., Ali, M., Ahmmed, F., Im, J., Islam, M. T., et al. (2020). Can cholera 'hotspots' be converted to cholera 'coldspots' in cholera endemic countries? The Matlab, Bangladesh experience. Int. J. Infect. Dis. 95, 28-31. doi: $10.1016 /$ j.ijid.2020.02.055 
Zemskova, Z. S., and Dorozhkova, I. R. (1991). Pathomorphological assessment of the therapeutic effect of mycobacteriophages in tuberculosis. Probl. Tuberk. 11, 63-66.

Zhang, H., Wang, R., and Bao, H. (2013). Phage inactivation of foodborne Shigella on ready-to-eat spiced chicken. Poult. Sci. 92, 211-217. doi: 10.3382/ps.201102037

Zhang, S. X., Zhou, Y. M., Tian, L. G., Chen, J. X., Tinoco-Torres, R., Serrano, E., et al. (2018). Antibiotic resistance and molecular characterization of diarrheagenic Escherichia coli and non-typhoidal Salmonella strains isolated from infections in Southwest China. Infect. Dis. Poverty 7:53. doi: 10.1186/ s40249-018-0427-2
Conflict of Interest: The authors declare that the research was conducted in the absence of any commercial or financial relationships that could be construed as a potential conflict of interest.

Copyright (๑) 2021 Khalid, Lin and Iredell. This is an open-access article distributed under the terms of the Creative Commons Attribution License (CC BY). The use, distribution or reproduction in other forums is permitted, provided the original author(s) and the copyright owner(s) are credited and that the original publication in this journal is cited, in accordance with accepted academic practice. No use, distribution or reproduction is permitted which does not comply with these terms. 